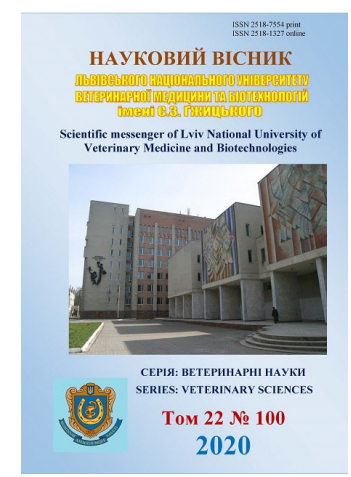

\author{
Науковий вісник Дьвівського націонадьного університету \\ ветеринарної медицини та біотехнологій імені С.3. Гжицького. \\ Серія: Ветеринарні науки \\ Scientific Messenger of Lviv National University \\ of Veterinary Medicine and Biotechnologies. \\ Series: Veterinary sciences
}

UDC 619:616.99:595.421

\title{
Seasonal activity of ixodid ticks in Podilskyi region
}

\author{
V. A. Levytska
}

State Agrarian and Engineering University in Podilya, Kamianets-Podilskyi, Ukraine

Article info

Received 05.10.2020 Received in revised form 05.11 .2020 Accepted 06.11.2020

State Agrarian and Engineering University in Podilya,

Shevchenko St., 13, KamianetsPodilskyi, 32300, Ukraine. Tel.: +38-067-381-20-12 E-mail:Levytska28@gmail.com
Levytska, V. A. (2020). Seasonal activity of ixodid ticks in Podilskyi region. Scientific Messenger of Lviv National University of Veterinary Medicine and Biotechnologies. Series: Veterinary sciences, 22(100), 66-70. doi: 10.32718/nvlvet10012

Ixodid ticks are the most important arthropod hematophagies in veterinary medicine. The spread of ticks and tick borne diseases is linked to human activities, including habitat change, deforestation, economic globalization, international animal movements, urbanization and climate change. The research was conducted from March 2018 to March 2019 in Khmelnytsky region. In total were collected 2086 D. reticulatus ticks and 658 I. ricinus ticks. During the studies, two peaks of seasonal activity of both species of ticks were observed according to the average number of specimens in the three study areas. Spring activity began in March, and the peak was observed in April. Males were found to be more active in March and the first half of April, while females dominated males from late May to late June. The second peak of activity in the study area began in mid-September. Since the beginning of September, the activity of ticks has increased almost eight times compared to August. The peak of autumn activity was observed in late October and early November. Active females dominated males from early October to late autumn. From mid-June to mid-September, single specimens of ticks were detected. During the winter, no ticks were found in the experimental plots. On average, in all experimental areas of Khmelnytsky region, ticks were active at a temperature of 10.8 to $27.8^{\circ} \mathrm{C}$ (average temperature $-21.6 \pm 6.57^{\circ} \mathrm{C}$ ) and humidity - 39.90-78.20\% (average humidity - 61.79\%). Statistical analysis performed for all study areas showed that air temperature significantly affected the activity of both species of ticks. However, correlations between the number of ticks collected and humidity throughout the study area and in different areas were not observed separately. The largest number of ticks was collected during the period when daylight lasted approximately 12-14 hours; in turn, the lowest number of ticks was detected on days with more than 15 hours of daylight. Statistical analysis confirmed the correlation between the length of daylight and the activity of ticks of both species.

Key words: ixodid ticks, Dermacentor reticulatus, Ixodes ricinus, Western Ukraine, temperature, humidity, peak activity.

\section{Сезонна активність іксодових кліщів в Подільському регіоні}

\author{
В. А. Левицька
}

Подільський державний аграрно-технічний університет, м. Кам'янець-Подільський, Україна

Іксодові кліщі є найважливішими членистоногими гематофагами у ветеринарній медицині. Широке поширення кліщів та трансмісивних захворювань пов'язане з діяльністю людини, включаючи зміни середовища існування, вирубування лісів, глобалізацію економіки, міжнародні переміщення тварин, урбанізацію та зміни клімату. Дослідження були проведені з березня 2018 року по березень 2019 року в Хмельницькій області. При вивченні сезонної активності іксодових кліщів, загалом було зібрано 2086 екземплярів D. reticulatus та 658 I. ricinus. Під час досліджень спостерігали два піки сезонної активності обох видів кліщів за середньою кількістю екземплярів на трьох досліджуваних ділянках. Весняна активність розпочалася в березні, а пік спостерігали у квітні. Встановлено, що самиі були більш активними в березні та першій половині квітня, тоді як самки домінували над самиями з кіния травня до кіния червня. Другий пік активності в досліджуваній зоні розпочався в середині вересня. 3 початку вересня активність кліщів зросла майже в вісім разів порівняно з серпнем. Пік осінньої активності був відзначений в кінці жовтня на початку листопада. Активні самки домінували над самиями з початку жовтня до кіния осені. 3 середини червня і до середини вересня виявляли 
поодинокі екземпляри клішів. У зимовий період на дослідних ділянках клішів виявлено не було. В середньому на всіх дослідних ділянках Хмельницької області кліщі були активними при температурі від 10,8 до 27,8 ${ }^{\circ} \mathrm{C}$ (середня температура - $21,6 \pm 6,57{ }^{\circ} \mathrm{C}$ ) та вологості повітря - 39,90-78,20\% (середня вологість - 61,79\%). Статистичний аналіз, проведений для всіх досліджуваних ділянок, показав, що температура повітря суттєво впливала на активність обох видів кліщів. Однак кореляції між кількістю зібраних кліщів та вологістю повітря на всій дослідній території та на різних ділянках окремо не спостерігали. Найбільша кількість кліщів була зібрана в період, коли світловий день тривав приблизно 12-14 годин; у свою чергу, найменша кількість кліщів була виявлена в дні з більш ніж 15 годинами світлового дня (тобто в червні, липні та серпні). Статистичний аналіз підтвердив кореляцію між тривалістю світлового дня та активністю кліщів обох видів.

Ключові слова: іксодові кліщуі, Dermacentor reticulatus, Ixodes ricinus, західна Украӥна, температура, вологість, пік активності.

\section{Вступ}

Іксодові кліщі є найважливішими членистоногими гематофагами у ветеринарній медицині (de la Fuente et al., 2008). Широке поширення кліщів та трансмісивних захворювань пов'язане з діяльністю людини, включаючи зміни середовища існування, вирубування лісів, глобалізацію економіки, міжнародні переміщення тварин, урбанізацію та зміни клімату (Harrus \& Baneth 2005; Krčmar et al., 2019).

Про вплив кліматичних змін на різноманіття фауни кліщів в Європі свідчить підвищена щільність і здатність кліщів поширюватися на нові території протягом останніх двох десятиліть (Beugnet \& Chalvet-Monfray, 2013). Існує гіпотеза про те, що тепліші зими і триваліші осінні та весняні сезони протягом останніх 15 років сприяють поширенню кліщів Dermacentor reticulatus і Ixodes ricinus у північні євразійські регіони та у гірські ландшафти, які раніше були непридатними для цих видів (Dantas-Torres, 2015). Крім того також зростає чисельність популяцій кліщів. Розширення ареалу існування та збільшення кількості кліщів підвищує ризик ураження тварин та людини патогенами, що вони переносять, наприклад найпростішими 3 роду Babesia, вірусом кліщового енцефаліту, рикетсіозами та іншими збудниками (Zając et al., 2016).

Сезонну активність кліщів D. reticulatus та I. ricinus неодноразово вивчали у східній, центральній та західній Європі, а також в деяких регіонах України (Buczek, 2014; Akimov \& Nebogatkin, 2016). Сезонна, а також пікова активність усіх іксодових кліщів значною мірою залежить від середовища їх існування, включаючи макро- та мікроклімат, тип рослинності та наявність тварин для живлення. Якщо кліматичні умови не сприятливі, іксодові кліщі можуть продовжити свій анабіотичний стан і пізніше вийти 3 діапаузи, а це може призвести до тимчасових коливань пікової активності кліщів, пов'язаних з різними біотопами (Hornok \& Farkas, 2009).

Окрім змін у поширеності та сезонній активності кліщів, кліматичні фактори також можуть спричиняти зміни у виборі живителів кліщами. Так, вид I. ricinus, якого раніше частіше виявляли на вівцях, які пасуться на відкритих пасовищах, частіше почали виявляти на диких жуйних тваринах, що мешкають у лісах (Genchi \& Manfredi, 1999). В підтримці епізоотологічних ланцюгів велике значення займають дикі тварини, які є резервуарами збудників та живителями для кліщів (Lorusso et al., 2011; D 'Amico et al., 2017).

У центральній Європі імаго кліщів активні протягом усього року, за виключенням морозної погоди та наявності снігового покриву. У зимовий час кліщі D. reticulatus вступають в стадію діапаузи з мінімальною метаболічною активністю. 3 поверненням плюсових температур вони знову активізуються. Еволюційна адаптація кліщів D. reticulatus до низьких температур дає їм перевагу над видом I. ricinus, який $\epsilon$ більш теплолюбивим видом (Hubálek et al., 2003; Kiewra et al., 2016; Zajac et al., 2020).

Сезонна активність іксодових кліщів прямо впливає на ризик ураження кліщовими захворюваннями людей та тварин. Для прогнозування даних ризиків необхідно знати, чи впливають певні біотичні чи абіотичні фактори на активність кліщів. У ряді досліджень було встановлено, що температура та вологість навколишнього середовища відіграють важливу роль у життєдіяльності кліщів, однак вплив цих двох факторів може відрізнятися в залежності від виду кліща, середовища існування та регіону (Schulz et al., 2014; Földvári et al., 2016). Отже, виявлення факторів, що впливають на поширення та активність іксодових кліщів, $\epsilon$ фундаментальним для епізоотологічних досліджень трансмісивних захворювань. Тому метою наших досліджень було дослідити сезонну активність кліщів на Поділлі України і встановити ії залежність від абіотичних факторів.

\section{Матеріал і методи досліджень}

Дослідження були проведені з березня 2018 року по березень 2019 року в Хмельницькій області. Було обрано три ділянки для спостережень: с. МукшаКитайгородська, с. Суржинці і с. Смотрич. Даний регіон характеризується наступними показниками: середня річна температура $7,5-7,9{ }^{\circ} \mathrm{C}$, сума температур за вегетаційний період, тривалість якого в середньому 163-167 днів - 2620-2680 ${ }^{\circ} \mathrm{C}$, величина гідротермічного коефіцієнту (ГТК) 1,4 , кількість опадів за вегетаційний період 428-430 мм, а за рік 576-690 мм, тривалість безморозного періоду 174-175 днів, стійкий сніговий покрив утворюється в третій декаді грудня, а руйнується в третій декаді лютого, середня висота снігового покриву $14-16 \mathrm{~cm}$.

Хмельниччина займає 20,6 тисячі квадратних кілометрів. I хоч в області нині ліси вкривають лише близько $13 \%$ території, та за розмаїттям флори, яка нараховує понад 1700 вищих спорових i насінних рослин, що належать до понад 100 родин і 500 родів (найчисельнішими серед них є лісові і степові види), i понад дві тисячі видів тварин, представлених безхребетними, рибами, земноводними, плазунами, птахами і ссавцями, область посідає третє місце в Україні після Криму та Карпат. Природні, нерозорані, площі 
займають ліси, луки, остепнені луки, кам'янисті ділянки, болота. Загальна площа лісів складає 284,2 тисячі гектарів, із них лісовою рослинністю вкрито 258,7 тисячі гектарів. Площа земель лісового фонду 191,5 тисячі гектарів. А близько 60 відсотків земель на Хмельниччині розорані.

У Хмельницькій області найбільш поширеними деревними лісовими породами є: дуб звичайний (Quercus robur L.) та скельний (Quercus petraea Liebl.), береза бородавчаста (Betula verrucosa Ehrh.), сосна звичайна (Pinus sylvestris L.), клен гостролистий (Acer platanoides L.), граб звичайний (Carpinus betulus L), вільха чорна (Alnus glutinosa Geartn.), осика (Populus tremula L).

Трав'яно-чагарниковий покрив - нещільний, переважно складений бореальними видами без чіткого домінування якогось із них: віхалкою гіллястою, ожикою волосистою, золотушником звичайним, вересом звичайним, веснівкою дволистою, щитником шартрським, одинарником європейським. Добре розвинений моховий ярус з плевроція Шребера та диктрана зморшкуватого (Timoshchuk et al., 2017).

Чисельність кліщів I. ricinus та D. reticulatus у навколишньому середовищі оцінювали окремо та сумарно для всіх трьох ділянок. Кліщів збирали “на прапор" $(1 \times 1$ м) в природніх біотопах. Збори проводили двічі на день у пік активності між 9-11 год ранку та 16-18 год ввечері. У день зборів реєстрували метеорологічні дані: мінімальна та максимальна добова температура повітря, температура повітря (1,5 м над поверхнею грунту) о 9.00 год ранку та о 15.00 год, вологість (\%), добові опади у мм та швидкість вітру $(\mathrm{M} / \mathrm{c})$ о 9.00 год та 15.00 год.

Кліщів зберігали в 96 \% етанолі та досліджували в лабораторії паразитології на кафедрі інфекційних та інвазійних хвороб Подільського державного аграрнотехнічного університету. Вид, стать та стадію розвитку визначали у кожного кліща окремо (Filippova, 1977).
Первинні дані проаналізовані стандартними методами, що застосовуються в біологічній статистиці, за допомогою електронних таблиць Excel.

\section{Результати досліджень}

При вивченні сезонної активності іксодових кліщів, загалом було зібрано 2086 екземплярів D. reticulatus та 658 I. ricinus.

Під час досліджень спостерігали два піки сезонної активності обох видів кліщів за середньою кількістю екземплярів на трьох досліджуваних ділянках (рис. 1). Весняна активність розпочалася в березні, а пік спостерігали у квітні. Встановлено, що самці були більш активними в березні та першій половині квітня, тоді як самки домінували над самцями 3 кінця травня до кінця червня.

Другий пік активності в досліджуваній зоні розпочався в середині вересня. 3 початку вересня активність кліщів зросла майже в вісім разів порівняно 3 серпнем. Пік осінньої активності був відзначений в кінці жовтня на початку листопада. Активні самки домінували над самцями 3 початку жовтня до кінця осені. Було встановлено статистично достовірні відмінності у активності кліщів навесні та восени на всіх трьох досліджуваних ділянках.

Під час досліджень найвища активність кліщів $D$. reticulatus була зареєстрована навесні (в середньому за годину збирали $18,45 \pm 6,08$ самок та $13,27 \pm 3,26$ самців), а восени була майже в 2 рази нижчою $(9,32 \pm 3,17$ та $6,78 \pm 2,79$ самок і самців відповідно).

При зборах кліщів виду I. ricinus навесні та восени також було виявлено приблизно вдвічі більше екземплярів кліщів. Для самок ці показники становили $10,15 \pm 4,36$ і 4,65 $\pm 2,89$, для самців - 7,98 $\pm 4,12$ i $3,23 \pm 1,18$ відповідно. Різниця була статистично достовірною (Р $<0,001)$.

3 середини червня і до середини вересня виявляли поодинокі екземпляри кліщів. У зимовий період на дослідних ділянках кліщів виявлено не було.

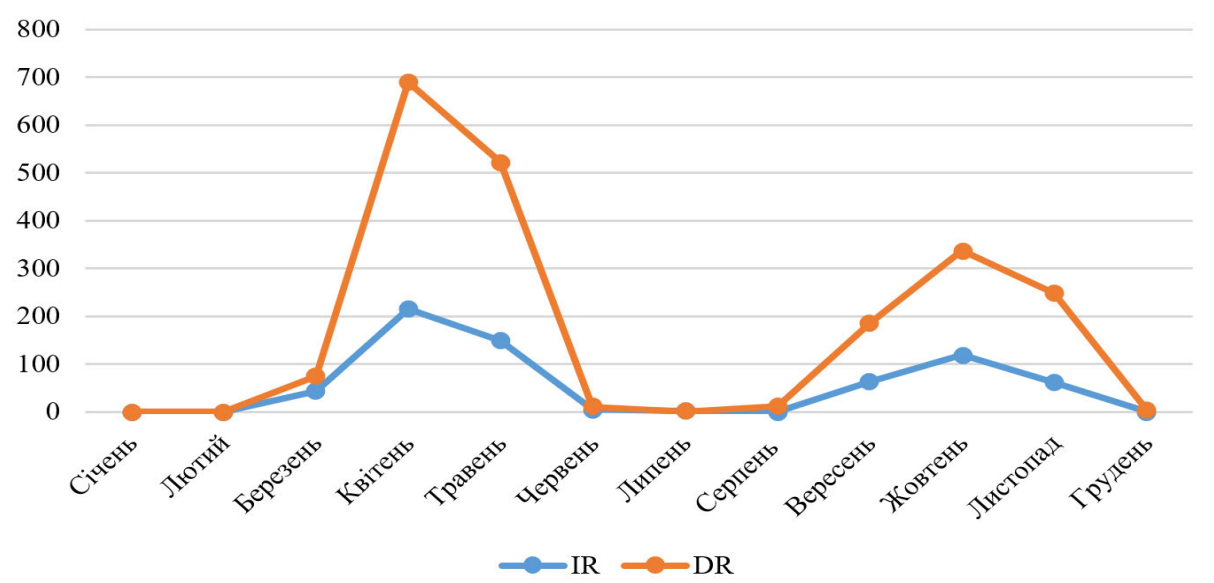

Рис. 1. Сезонна динаміка чисельності кліщів у Хмельницькій області протягом 2018 року

В середньому на всіх дослідних ділянках Хмельницької області кліщі були активними при температурі від 11,8 до $27,8{ }^{\circ} \mathrm{C}$ (середня температура - $\left.21,6 \pm 6,57{ }^{\circ} \mathrm{C}\right)$ та вологості повітря - 39,90-78,20 \% (середня вологість - 61,79\%). Статистичний аналіз, проведений для всіх досліджуваних ділянок, показав, 
що температура повітря суттєво впливала на активність обох видів кліщів. Однак кореляції між кількістю зібраних кліщів та вологістю повітря на всій дослідній території та на різних ділянках окремо не спостерігали.

Найбільша кількість кліщів була зібрана в період, коли світловий день тривав приблизно 12-14 годин; у свою чергу, найменша кількість кліщів була виявлена в дні 3 більш ніж 15 годинами світлового дня (червень-серпень). Статистичний аналіз підтвердив кореляцію між тривалістю світлового дня та активністю кліщів обох видів.

\section{Обговорення}

Протягом року дослідження температура та вологість значно коливалися. Нами не було встановлено залежності між вологістю повітря та активністю самок і самців, однак існувала кореляція між температурою та активністю іксодових кліщів, а також між тривалістю фотоперіоду та активністю кліщів D. reticulatus i I. ricinus.

За даними Хмельницького обласного центру з гідрометеорології середня річна температура повітря у 2018 році становила $8,9{ }^{\circ} \mathrm{C}$. Середня річна кількість опадів у 2018 році становила 573 мм. Проаналізувавши дані спостережень за останні п'ять років, середня температура набула тенденції до збільшення. Порівняно з 2014 роком значення середньої температури у 2018 році збільшилося $3+8,6{ }^{\circ} \mathrm{C}$ до $+8,9{ }^{\circ} \mathrm{C}$. Щодо кількості опадів, то спостерігалося значне зменшення опадів з 635 мм (у 2014 році) до 573 мм (у 2018 році). Отже, дана тенденція свідчить про виникнення більш сприятливих умов для існування кліщів, а також пояснює збільшення кількості популяцій і активність протягом зимових місяців, яку було виявлено у наших попередніх дослідженнях (Levytska \& Mushynskyi, 2020).

Вважається, що глобальне потепління та погодні умови можуть сприяти розширенню ареалів кліщів та змінам динаміки їхньої активності та сезонних піків кліщових захворювань. Сучасні дослідження показали, що висока активність кліщів може зберігатися навіть протягом усього грудня, протягом найкоротших днів року при температурі грунту та повітря $5 \mathrm{C}$ (Gilbert, 2010; Buczek et al., 2014). Це пов'язано iз підвищенням середньорічної температури, більшою кількістю сонячних днів і коротшим періодом або відсутністю снігового покриву. Крім того, кліщі D. reticulatus добре пристосовуються до значних коливань температури і вологості, що може пояснити експансію виду на нові території (Földvári et al., 2016). Однак у наших дослідженнях протягом зимових місяців спостерігалась температура нижче $0{ }^{\circ} \mathrm{C}$, що очевидно було причиною відсутності кліщів.

Домінування кількості самок над самцями, про яке повідомляють інші дослідники також, можна пояснити тим, що збори проводили у затінених місцях, а не на відкритих ділянках і луках. Дане явище можна пояснити різницею в морфології (ступінь хітинізації поверхні тіла) та фізіології між двома статями, а та- кож різними вимогами до температури та вологості. Оскільки самки піддаються підвищеному ризику втрати води, вони знижують свою активність у несприятливих умовах. У попередньому дослідженні авторів, проведеному в різних типах середовищ існування у Польщі, було виявлено, що самки виявляли найвищу активність при температурі $20{ }^{\circ} \mathrm{C}$ і $65 \%$ вологості, а самці при $18^{\circ} \mathrm{C}$ та $60 \%$ відповідно (Buczek et al., 2014).

Наші дослідження співпадають 3 дослідженнями проведеними у Польщі, Хорватії, Словаччині, які підтверджують, що чисельність та активність кліщів D. reticulatus та I. ricinus залежать від умов середовища існування, які визначаються характерною флорою, яка визначається кліматом та грунтами та наявністю певних видів тварин. Лугові екосистеми, які межують iз лісистими ділянками та водоймами, створюють найбільш сприятливі умови для розвитку цих видів кліщів у зонах де відсутній антропогенний вплив. Такі середовища існування забезпечують присутність багатьох видів тварин, які можуть бути живителями для преімагінальних стадій кліщів та імаго кліщів (Földvári et al., 2016; Akimov \& Nebogatkin, 2016).

\section{Висновки}

Результати наших досліджень підкреслюють важливість моніторингу тимчасового та просторового розподілу іксодових кліщів для оцінки потенційного довгострокового впливу кліматичного потепління та більш “м’яких” зим.

\section{References}

Akimov, I. A., \& Nebogatkin, I. V. (2016) Ticks urban landscapes of Kyiv (in Ukrainian).

Beugnet, F., \& Chalvet-Monfray, K. (2013). Impact of climate change in the epidemiology of vector-borne diseases in domestic carnivores. Comparative immunology, microbiology and infectious diseases, 36(6), 559-566. doi: 10.1016/j.cimid.2013.07.003.

Buczek, A., Bartosik, K., \& Zając, Z. (2014). Changes in the activity of adult stages of Dermacentor reticulatus (Ixodida: Amblyommidae) induced by weather factors in eastern Poland. Parasites \& vectors, 7, 245. doi: 10.1186/1756-3305-7-245.

D'Amico, G., Dumitrache, M. O., Matei, I. A., Ionică, A. M., Gherman, C. M., Sándor, A. D., Modrý, D., \& Mihalca, A. D. (2017). Ixodid ticks parasitizing wild carnivores in Romania. Experimental \& applied acarology, 71(2), 139-149. doi: 10.1007/s10493-017-0108-z.

Dantas-Torres, F. (2015). Climate change, biodiversity, ticks and tick-borne diseases: The butterfly effect. International journal for parasitology. Parasites and wildlife, 4(3), 452-461. doi: 10.1016/j.ijppaw.2015.07.001.

de la Fuente, J., Estrada-Pena, A., Venzal, J. M., Kocan, K. M., \& Sonenshine, D. E. (2008). Overview: Ticks as vectors of pathogens that cause disease in humans and animals. Frontiers in bioscience : a journal and virtual library, 13, 6938-6946. doi: 10.2741/3200. 
Filippova, N. A. (1977). Iksodovi klishchi pidrodyny Ixodinae. Fauna SRSR. Arakhnida. Leninhrad, Vydavnytstvo. Nauka (in Ukrainian).

Földvári, G., Široký, P., Szekeres, S., Majoros, G., \& Sprong, H. (2016). Dermacentor reticulatus: a vector on the rise. Parasites \& vectors, 9(1), 314. doi: 10.1186/s13071-016-1599-x.

Genchi, C., \& Manfredi, M. T. (1999). Tick species infesting ruminants in Italy: ecological and bio-climatic factors affecting the different regional distribution. Parassitologia, 41(1), 41-45.

Gilbert, L. (2010). Altitudinal patterns of tick and host abundance: a potential role for climate change in regulating tick-borne diseases?. Oecologia, 162(1), 217225. doi: 10.1007/s00442-009-1430-x.

Harrus, S., \& Baneth, G. (2005). Drivers for the emergence and reemergence of vector-borne protozoal and bacterial diseases. Int. J. Parasitol, 35(11-12), 13091318. doi: 10.1016/j.ijpara.2005.06.005.

Hornok, S., \& Farkas, R. (2009). Influence of biotope on the distribution and peak activity of questing ixodid ticks in Hungary. Medical and veterinary entomology, 23(1), 41-46. doi: 10.1111/j.1365-2915.2008.00768.x.

Hubálek, Z., Halouzka, J., \& Juricová, Z. (2003). Hostseeking activity of ixodid ticks in relation to weather variables. Journal of vector ecology. Journal of the Society for Vector Ecology, 28(2), 159-165. URL: https://europepmc.org/article/med/14714663.

Kiewra, D., Czułowska, A., \& Lonc, E. (2016). Winter activity of Dermacentor reticulatus (Fabricius, 1794) in the newly emerging population of Lower Silesia, south-west Poland. Ticks and tick-borne diseases, 7(6), 1124-1127. doi: 10.1016/j.ttbdis.2016.08.012.

Krčmar, S. (2019). Diversity, ecology, and seasonality of hard ticks (Acari: Ixodidae) in eastern Croatia. Journal of vector ecology: journal of the Society for Vector Ecology, 44(1), 18-29. doi: 10.1111/jvec.12325.

Levytska, V. A., \& Mushynskyi, A. B. (2020). Ixodid ticks in the Western Ukraine. Scientific Messenger of Lviv National University of Veterinary Medicine and Biotechnologies. Series: Veterinary sciences, 22(97), 187-193. doi: 10.32718/nvlvet9730.

Lorusso, V., Lia, R. P., Dantas-Torres, F., Mallia, E., Ravagnan, S., Capelli, G., \& Otranto, D. (2011). Ixodid ticks of road-killed wildlife species in southern Italy: new tick-host associations and locality records. Experimental \& applied acarology, 55(3), 293300. doi: 10.1007/s10493-011-9470-4.

Schulz, M., Mahling, M., \& Pfister, K. (2014). Abundance and seasonal activity of questing Ixodes ricinus ticks in their natural habitats in southern Germany in 2011. Journal of vector ecology. Journal of the Society for Vector Ecology, 39(1), 56-65. doi: 10.1111/j.19487134.2014.12070.x

Timoshchuk, O. O., Zvedenyuk, M. A., \& Klymchuk, V. V. (2017) Forests of Khmelnytsky region. Popular science publication. Khmelnytsky: Polygraphist LLC.

Zając, Z., Bartosik, K., \& Woźniak, A. (2020). Monitoring Dermacentor reticulatus Host-Seeking Activity in Natural Conditions. Insects, 11(5), 264. doi: 10.3390/insects11050264.

Zając, Z., Katarzyna, B., \& Buczek, A. (2016). Factors influencing the distribution and activity of Dermacentor reticulatus (F.) ticks in an anthropopressureunaffected area in central-eastern Poland. Annals of agricultural and environmental medicine. AAEM, 23(2), 270-275. doi: 10.5604/12321966.1203889. 